\title{
The Transformation of Obscenity Law Jacob Rowbottom*
}

\section{Introduction}

For many years, the law of obscenity was taught in university constitutional law courses as an issue concerning civil liberties and freedom of speech. On the course, obscenity was often explained within a narrative of the authorities seeking to suppress the speech it disagrees with or to enforce the values held by the establishment. When I first studied law and began teaching, the leading cases seemed sufficiently distant to be looked upon with some humour and a sense of nostalgia. The kind of material targeted by the authorities and which caused alarm in the 1960s, 70s and 80s seemed relatively tame by contemporary standards. As a result of the wave of constitutional reforms in the late 1990s, the course syllabus became increasingly squeezed. Obscenity was seen to be of marginal importance compared with other constitutional issues and was no longer taught on the course.

The Obscene Publications Act 1959 has certainly declined in importance in the last two decades. In 2015, there were only 2 convictions under s. 2 of the Obscene Publications Act in England and Wales, and in 2016 there were 5 convictions under the same provision. ${ }^{1}$ However, when looking at a broad category of obscenity related offences in the aggregate, there are more convictions than ever. This article seeks to take stock and look at the general trends in obscenity related offences. While some obscene publications offences have largely fallen by the wayside, new offences have been introduced and some older offences have taken on a new lease of life in the digital era. This article will look at the available statistics to see what is happening in the area and to identify further questions.

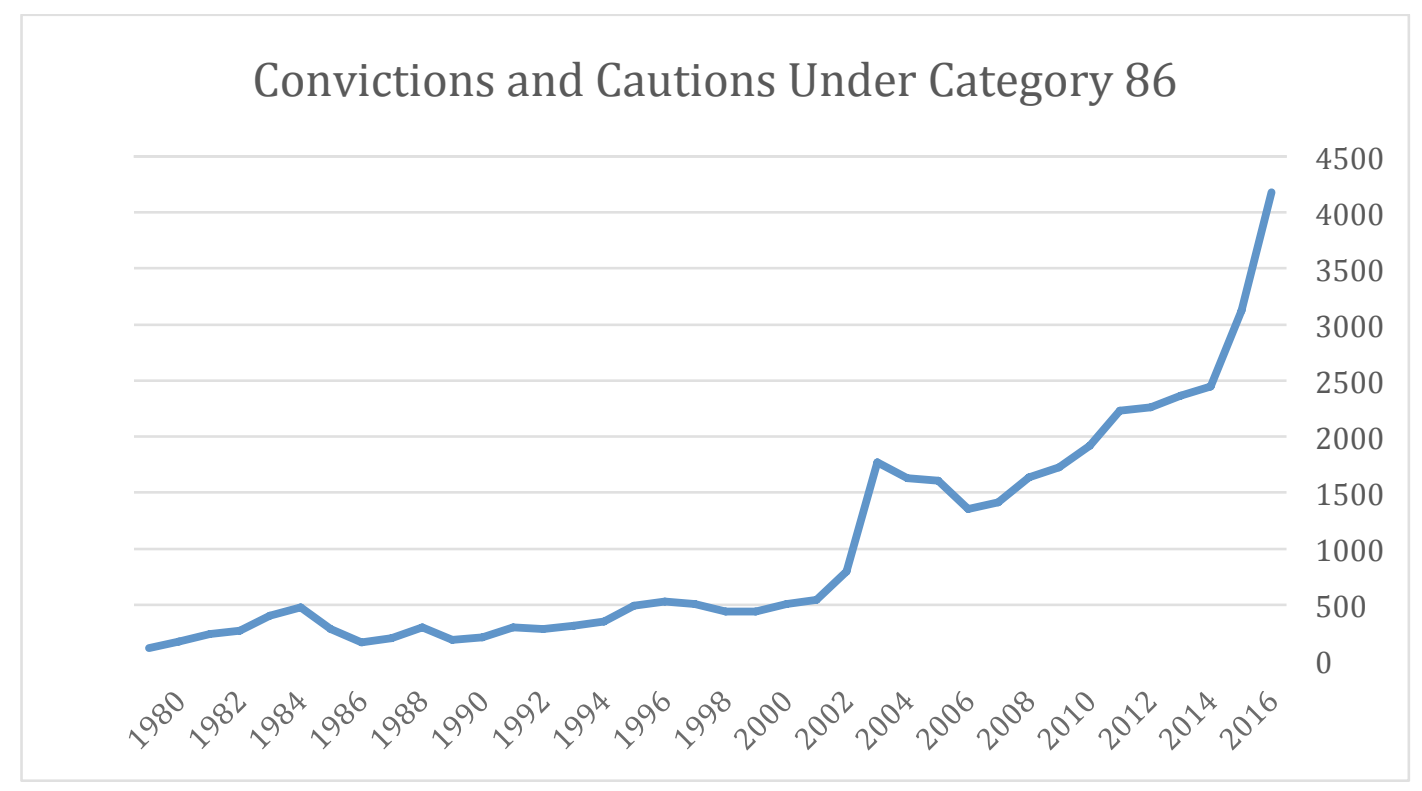

\footnotetext{
* Associate Professor, Faculty of Law, Oxford and Tutorial Fellow, University College Oxford. Thanks are due to the anonymous reviewer for comments on an earlier draft and to Prof Julian Roberts for discussing the criminal justice statistics.

${ }^{1}$ Ministry of Justice, Criminal Justice System Statistics Quarterly: December 2016 (May 2017) (for 2016).
} 
The starting point for analysis are the official statistics on offences by outcome. For a number of years, the Ministry of Justice and previously the Home Office have provided statistics for several indictable obscenity related offences in England and Wales grouped together under category 86, which includes offences under the Obscene Publications Act 1959, the Protection of Children Act 1978 and the Video Recordings Act $1984 .^{2}$ The aggregated statistics paint a remarkable picture, giving the impression of considerable growth rather than decline in this area of law. For example, while the authorities in the early 1980s famously sought to crackdown on various types of obscene content, the number of convictions and cautions under this category in 1984 was less than a eighth of those convicted and cautioned under the same group of offences in 2016. If the obscenity related offences ever enjoyed a heyday, then the aggregate statistics suggest we are living through it now.

The picture is more complicated. In some respects, the offences grouped together are not comparable and deal with various different problems. In so far as possible, this article will disaggregate the statistics to look at the key criminal offences grouped under category 86 , the circumstances in which the offences were introduced and the patterns in convictions (where data is available). There are a number of challenges in collecting the data, which is taken from different sources. In some cases, the data is drawn from official Home Office and Ministry of Justice statistics. In other cases, the data is drawn from answers to parliamentary questions. In some years, the data is unavailable. The collection of data from piecemeal sources means that in some places there are gaps and minor inconsistencies in the statistics. The full data collected is provided in the appendix to this article.

The data is most commonly provided on a principal offence basis, which means that where a person is charged with two offences, the statistic is provided for the offence which attracted the heaviest penalty or (if the same level of penalty was given for both offences) which carries the heaviest maximum penalty. However, in the group of offences considered here, it is not uncommon for defendants to be charged with more than one offence (for example 'making' and 'possessing' indecent images of children). The statistics may thereby indicate higher statistics for the more serious offences, while masking the less serious offences. A further complication is that in some of the earlier statistics, the sources state that the data includes 'persons proceeded against in earlier years or for other offences', but does not state whether the data is recorded on a principal offence basis or whether a more inclusive figure is provided. Given these limits, it is important to show caution when analysing the data. More broadly, Susan Edwards has warned that the data can give a misleading picture if the prosecution and convictions data are compared to calculate the success of convictions. ${ }^{3}$ While the relevant data is provided in some of the tables in the appendix, no claim about the conviction rate is made here.

\footnotetext{
${ }^{2}$ The offences currently included in offence category 86 relate to the production and possession of indecent images of children; the display of indecent matter; publication of obscene material; the supply of unclassified videos; and offences relating to protected material.

${ }^{3}$ S. Edwards, 'On the contemporary application of the Obscene Publications Act 1959' (1998) Crim.

L.R. 843 at $846-847$.
} 
Despite these limits, the available data is nonetheless useful in identifying some broad trends and the numbers help to give an indication of the direction of travel in this area. It will be shown that some offences have moved away from the original rationale for enactment and have been adapted to contemporary problems. That is not objectionable in itself, but it is worth looking at the broad trends to take stock and evaluate a strategy that appears to draw more people than ever into the criminal justice system.

\section{Obscene Publications Acts}

The Obscene Publications Act 1959 is one of the best-known controls on pornographic and other types of 'corrupting content'. It enjoys both fame and notoriety, having played a role in battles at the heart of a cultural change in Britain. These battles include famous cases such as the prosecutions relating to Lady Chatterley's Lover, Last Exit to Brooklyn, Oz Magazine and later in relation to the socalled 'video nasties'. These battles now seem quaint with the passage of time and such high-profile prosecutions of well-known publications appear to be largely a thing of the past.

The law of obscenity has a long history in the UK, first being recognised as a common law offence of obscene libel in the 1727 decision King $v$ Curl, which concerned the publication of two books, The Nun in her Smock and The Art of Flogging. ${ }^{4}$ The offence became more widely enforced during the $19^{\text {th }}$ century with private prosecutions being brought by voluntary organisations, most notably the Society for the Suppression of Vice. ${ }^{5}$ When the Society found itself frustrated with the limited effectiveness of criminal penalties being applied after the material had been published and circulated, it found a supporter in Lord Campbell who introduced the Obscene Publications Act 1857 to give the police new powers to search and seize obscene material. ${ }^{6}$ The exercise of the powers under the 1857 Act led to the famous decision in Hicklin, in which an obscene publication was defined as one that would 'deprave and corrupt those whose minds are open to such immoral influences, and into whose hands a publication of this sort may fall.,

Despite the potential breadth of the offence, the number of convictions in the earlier decades of the 20th century was often relatively small by today's standards. In 1938, there were 39 convictions for the common law offence of publishing an obscene libel. ${ }^{8}$ While the $1950 \mathrm{~s}$ are remembered as a fairly repressed period in terms of media content, in 1951 there were 51 convictions and in 1954 there were 111 convictions for the common law offence of obscene libel, which were both the high points for the earlier part of that decade. ${ }^{9}$ However, it is hard to draw too many conclusions from these numbers, as the relatively low numbers may simply reflect a higher level of

\footnotetext{
${ }^{4}$ King v Curl (1727) 1 Barn. K.B. 29

${ }^{5}$ M.J.D. Roberts, 'Making Victorian morals? The society for the suppression of vice and its critics, 1802-1886' (1984) 21 Historical Studies 157.

${ }^{6}$ C. Manchester, 'Lord Campbell's act: England's first obscenity statute' (1988) 9 The Journal of Legal History 223.

${ }^{7} R v$ Hicklin (1868) 3 Q.B. 360

${ }^{8}$ Appendix B in Minutes of Evidence taken the Select Committee of the Obscene Publications Bill 1956-57 (122) (1958).

${ }^{9}$ Ibid.
} 
compliance with the law. What makes the earlier eras stand out is not so much the number of prosecutions, but the types of content being prosecuted, which included a number of novels. ${ }^{10}$

A House of Commons Select Committee reviewed the law of obscenity in 1957 and 1958 , the recommendations of which led to the enactment of the Obscene Publications Act in 1959. Under s.2 of the 1959 Act, it is an offence to publish an obscene article, with obscenity defined under s.1 as matter that would 'tend to deprave and corrupt persons who are likely, having regard to all relevant circumstances, to read, see or hear the matter contained or embodied in it'. ${ }^{11}$ The 1959 Act sought to liberalise the law in three main respects: (1) applying the deprave and corrupt test only to the 'likely reader' and not to any person into whose hands the publication might fall; (2) requiring the court to judge the article as a whole and not isolated passages; and (3) including a public good defence. ${ }^{12}$ Despite the liberalising intent of the law, the standard of obscenity continued to have a broad application and was not restricted to pornographic material. Images of war (such as a drawing of a torture chamber) on chewing gum cards targeted at children, for example, had been found capable of being obscene. ${ }^{13}$

The available statistics show fluctuations in the use of s.2 of the Act. The mid-1970s shows a relatively high usage of the Act with 433 convictions in 1974. This use of the Act also came at a time when the boundaries relating to sexual content were changing. While the 1960s produced the high-profile trials relating to Oz Magazine and Last Exit to Brooklyn, which helped to open the doors for changing standards, the 1970s saw significant circulations in pornography that had little claim to artistic merit and continued to test the system. ${ }^{14}$ The higher number of convictions should not simply be understood as a sign of a more repressed era, but may rather reflect the response of the authorities to a more liberal environment when people felt able to push the boundaries on what is acceptable.

Another peak in convictions can be seen in the mid-1980s, particularly in 1984, which saw 429 convictions. This period coincides with the height of the panic concerning the so-called 'video nasties', in which the DPP drew up a list of films that were thought to be appropriate for prosecution. During the period, the crackdown also saw different courts taking differing reactions to the same content, which increased the level of uncertainty for distributors of the videos. A jury in Leeds acquitted a video shop selling a number of 'nasties' including The Evil Dead in $1984,{ }^{15}$ while magistrates fined a video dealer for possessing several videos for gain, including that same film. ${ }^{16}$ As a sign of how standards have changed, over two decades later, free

\footnotetext{
${ }^{10}$ See G. Robertson, Obscenity (Weidenfeld and Nicolson, 1979) at p.41-42 on a series of prosecutions in 1954.

${ }^{11}$ The Obscene Publications Act 1964, added that the offence under s.2 of the 1959 Act is committed if 'he has the article in his ownership, possession or control' with a view to publication for gain.

${ }^{12}$ B. Williams (Chair), Report of the Committee on Obscenity and Film Censorship (Cmnd 7772, 1979) p. 170 .

${ }^{13}$ DPP v. A. and B.C. Chewing Gum Ltd. [1968] 1 Q.B. 159.

${ }^{14}$ See Williams Committee, n 12 above, Appendix 6.

15 'Doubts remain after ''obscene' video test case' The Guardian, 26 May 1984.

${ }^{16}$ The defendant, however, pleaded guilty, so the issue was not tested before the magistrates,

"'Obscene" video is an 18-certificate film' The Guardian, 26 January 1984.
} 
dvds of The Evil Dead were being given away by a best-selling tabloid newspaper ${ }^{17}$ and titles on the DPP's list can now be found in celebratory boxed sets of 'banned' films.

The confusion that followed the 'video-nasties' campaign also led to the enactment of the Video Recordings Act 1984, which provides that it is an offence to supply or offer to supply 'a video recording containing a video work in respect of which no classification certificate has been issued'. ${ }^{18}$ If the video has a classification from the British Board of Film Classification (BBFC), then it is also an offence to supply it in breach of any age restriction included in the classification certificate. ${ }^{19}$ The measure means that prosecutors generally do not need to consider the deprave and corrupt standard in relation to dvds, and the BBFC has a bigger role in deciding what content is permissible. Once this measure was enacted, there was less need to rely on the Obscene Publications Act and the authorities could rely on the administrative controls of certification, which partly explains the drop in prosecutions under s.2 of the 1959 Act in the following years. ${ }^{20}$ The Video Recordings Act 1984 therefore applied a significant control on suppliers of video, and in 2002 there were 62 convictions under the 1984 Act for the supply of an unclassified video. ${ }^{21}$ However, as video and dvd continue to decline as a means for distributing audio-visual content, the enforcement of the Act is now relatively low. In 2015, there was just one conviction for supplying an unclassified video, and four convictions for possessing an unclassified video with the purpose of supply. ${ }^{22}$ In 2016 , there were 5 convictions for the former offence, and none for the latter. ${ }^{23}$

\section{Convictions under s. 2 of the Obscene Publications Act 1959}

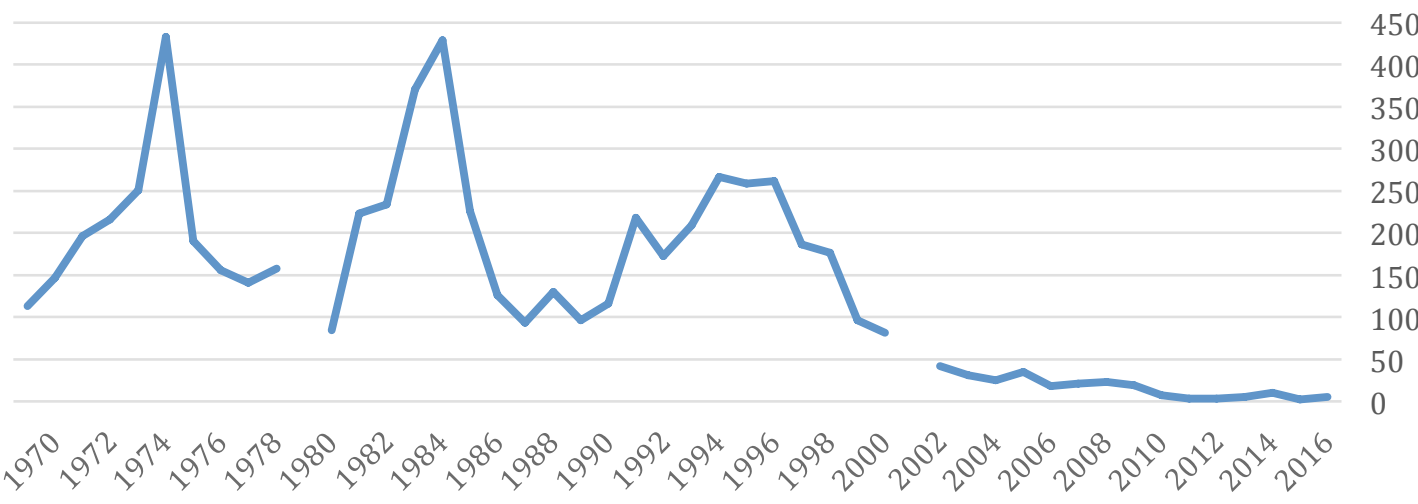

\footnotetext{
${ }^{17}$ The Sun, 'Free horror DVDs' 13 March 2007.

${ }^{18}$ S.9. See also $\mathrm{s} .10$ for possession for the purposes of supply.

${ }^{19}$ S.11.

${ }^{20}$ In 1988, the law was amended to give trading standards officers the power to enforce the Video Recordings Act, as in the first two and half years of the Act there had only been 2 prosecutions, which had been attributed to a lack of police manpower. The Sunday Times, 'New crackdown on video nasties' 13 March 1988.

${ }^{21}$ HC Deb, 16 February 2006, vol 442, col 2352W

${ }^{22}$ Ministry of Justice, Criminal Justice System Statistics Quarterly: December 2016 (May 2017).

${ }^{23}$ Ibid.
} 
The convictions under the Obscene Publications Act 1959 vary from year to year, but remained mostly in the low hundreds in the later 80 s and $90 \mathrm{~s}$. A slight increase can be seen in the 1990s, which coincides with a time of increasing concerns about a black market in hardcore pornography. By the later 1990s, the British Board of Film Classification and, in particular, the Video Appeals Committee (the committee set up to hear appeals from the BBFC in relation to classifications decisions), experimented with more liberal policies in relation to pornographic content, which allowed stronger sexual content to be certified. That policy generated some controversy and the Labour Government, elected in 1997, expressed its disapproval. ${ }^{24}$ The episode ended when the liberal policy of the Video Appeals Committee was found to be lawful by the High Court in judicial review proceedings. ${ }^{25}$ The BBFC subsequently drew up new guidelines for certification that allowed greater sexual content under the R18 certificates. This had an impact in liberalising the law of obscenity, as once a film is certified it is unlikely to be the subject of a prosecution. After the decision in the Video Appeals Committee case, a significant drop in the use of the Obscene Publications Act can be seen. In 2002, the figure dropped down to 42 convictions. In 2015 , there were a mere 2 convictions under s. 2 of the Act.

While the decreasing use of the Obscene Publications Act 1959 seems to fit with more liberal standards, it is also surprising at a time when increasing internet access has facilitated the dissemination of more extreme content. As a result, the 2000s proved to be a period where the boundaries were being pushed more than ever, yet that did not result in greater uptake in using the Act to control the flow of content. Instead, as will be shown, the types of content that did cause significant concern to the authorities were dealt with under more specific statutory provisions.

Despite the decline in use, the Act has still been used for some cases relating to digital communications. The case of Perrin concerned a pornographic website that was uploaded and hosted overseas, but the content was accessible within jurisdiction. ${ }^{26}$ The person responsible for the site was convicted under the Obscene Publications Act in relation to those parts of the site that were freely available and did not require a credit card for access. The Court of Appeal upheld the conviction on the basis that the publication occurs whenever the material is accessed within jurisdiction. The court reasoned that the fact that the material was freely available meant that the likely reader, to whom the deprave and corrupt test would be applied, includes children. ${ }^{27}$ The decision in Perrin shows the broad reach of the Obscene Publications Act in relation to the internet, both in the definition of a publication and in determining the likely reader. The decision suggests that the Act could be more widely used in relation to internet publications, yet the statistics show that is not happening. The application of the law is still constrained by the practical limits on enforcement.

The Obscene Publications Act 1959 is also used as a gap filler. In GS (2012), the defendant was convicted in relation to a conversation conducted via an internet chat service 'concerning incestuous, sadistic paedophile sex acts on young and very young

\footnotetext{
${ }^{24}$ The Sunday Times, 23 November 1997.

${ }^{25} R v$ Video Appeals Committee of the British Board of Film Classification, ex parte the British Board of Film Classification [2000] EMLR 850.

${ }^{26} R v$ Perrin [2002] EWCA Crim 747.

${ }^{27}$ Perrin, ibid, at [22].
} 
children' ${ }^{28}$ As this message did not contain an image, the criminal laws targeting child pornography were not applicable. ${ }^{29}$ The decision broke new ground in so far as it applied the statute to a private conversation between consenting adults. While the 1959 Act has always been applicable to one-to-one communications, the chances of such actions being detected were slim unless the other person was an unwilling recipient of the content. The case shows how the trail left by digital communications opens up the possibility for a wider range of speech and conversations to be discoverable by the authorities. While the Obscene Publications Act 1959 is no longer as widely used by prosecutors, it still provides a broad catch-all offence when other more specific offences do not apply.

It is, of course, a mistake to look solely at the prosecution and conviction statistics to get an understanding of what is happening with the Obscene Publications Act 1959. Section 3 of the 1959 Act provides the police with powers to search and seize material following an application to the magistrates' court, and is a successor to the powers granted under Lord Campbell's Act of 1857. The powers have played a central role in the 'street level' controls on the circulation of obscene publications. The Williams Committee reported that in 1978 magistrates made 550 orders to forfeit obscene articles and in the same year the Metropolitan Police seized 1,229,111 obscene items. ${ }^{30}$ In 1987, the Metropolitan Police seized 813,243 obscene items. ${ }^{31}$ These powers are also significant in so far as it gives the police a broad discretion to decide what type of content is obscene or not. In the 1970s, a Sun Page 3 calendar, for example, was reportedly seized by police in Manchester. ${ }^{32}$ A decade ago, the police in Manchester seized a t-shirt with the slogan 'Gunchester', on the grounds that it promoted gun crime. ${ }^{33}$ The $\mathrm{s} .3$ powers can continue to provide a significant control even as other statutes tend to be used more for prosecutions.

\section{Protection of Children}

While the Obscene Publications Act 1959 has declined in use, the use of the Protection of Children Act 1978, which criminalises the production and distribution of indecent images of children, has increased dramatically. The 1978 Act was a product of a cultural battle playing out in the 1970s. The case for legislation to protect children was driven outside Parliament by a campaign headed by Mary Whitehouse, a famous campaigner who had led attacks on numerous aspects of the 'permissive society'. As President of the National Viewers' and Listeners' Association, she had been at the forefront of attacks on representations of sex and violence on television and she had brought a private prosecution for blasphemy against the publication Gay News. ${ }^{34}$ Drawing on evidence from the USA and through her skilled use of publicity,

\footnotetext{
${ }^{28} R v G S$ [2012] EWCA Crim 398.

${ }^{29}$ When enacting the Protection of Children Act 1978, an amendment to include text within the ambit of the offence was not accepted.

${ }^{30}$ Williams Committee, n 12 above, p.264.

${ }^{31}$ HC Deb, 13 July 1992, vol 211, col WA496, the figure is the highest for the years 1985-1992

provided in the written answer.

${ }^{32}$ Robertson, $\mathrm{n} 10$, above.

33 “"Depraved" gun T-shirts banned' Manchester Evening News, 1 September 2007.

${ }^{34} R$ v Lemon [1979] A.C. 617.
} 
she worked to mobilise press attention on the issue of child pornography. ${ }^{35}$ In 1978 , half a million people were reported to have signed a petition calling for Parliament to act to take steps to combat the problem.

The Protection of Children Act 1978 was introduced as a Private Member's Bill in the House of Commons by the MP Cyril Townsend. Proponents of the legislation argued that legislative change was necessary due to a number of gaps in the law at the time. ${ }^{36}$ For example, the offence of sexual assault would not be committed where the maker of an indecent image had not touched the child. The Indecency with Children Act 1960 protected only children under $14 .{ }^{37}$ The Obscene Publications Acts only applied when an image was shown or put into circulation, but did not restrict the taking of an image.

The necessity of the legislation was subject to some debate. The gap in the law could have been partly addressed by raising the age of those protected by the Indecency with Children Act 1960 to cover those under $16 .^{38}$ There was also some disagreement about the extent of the problem. While the sponsor of the Bill claimed that images of children accounted for $5 \%$ of pornographic material seized in Manchester, the government minister Brynmor John claimed the evidence they had received did not support this figure. ${ }^{39}$ Despite the scepticism, the Labour government was in a weak position, with a minority in Parliament and potentially facing an election that year. The government thereby made the calculation that opposing the Bill was not worth the political cost from the Whitehouse campaign, the press and religious groups. ${ }^{40}$ The government claimed that the existing law was sufficient for most cases, though it welcomed the Act for providing an additional tool for the authorities. ${ }^{41}$

The Bill was enacted with little opposition. It passed its second reading in the Commons without a vote. In a study published in 1981, McCarthy and Moodie write that the bill was 'bulldozed through Parliament' in way that had not previously been seen with legislation on a major moral question. ${ }^{42}$ On the process of getting the Bill enacted, they wrote that:

'Fact was largely eschewed in favour of emotive supposition, the actual was ignored in favour of the potential and the remotely possible was selectively interpreted as imminently probable'. ${ }^{43}$

The Williams Committee also received no evidence that such images were a growing problem, and indicated that the Act was merely an interim measure pending a further overhaul of the obscenity laws. ${ }^{44}$ The Whitehouse campaign did not, however, get

\footnotetext{
${ }^{35}$ M.A. McCarthy and R. A. Moodie, 'Parliament and Pornography: The 1978 Child Protection Act' (1981) 34 Parliamentary Affairs 47 at 49.

${ }^{36}$ See Baroness Faithful introducing the Bill into the Lords, HL Deb, 5 May 1978, vol 391, col 537.

${ }^{37}$ Sir Michael Havers, HC Deb, 10 Feb 1978, vol 943, col 1894.

${ }^{38}$ Robertson, $\mathrm{n} 10$ above, p.301.

${ }^{39}$ Brynmor John, Hansard 10 Feb 1978, vol 943 col 1844.

${ }^{40}$ McCarthy and Moodie, n 35 above, at 54. Robertson, n 10 above, p.301.

${ }^{41}$ Lord Harris, HL Deb, 5 May 1978, vol 391, col 574-578. See also Lord Wigdoer HL Deb, 5 May 1978, vol 391, at col 542.

${ }^{42}$ McCarthy and Moodie, n 35 above, at 61.

${ }^{43}$ McCarthy and Moodie, n 35 above, at 61.

${ }^{44}$ Williams Committee, n 12 above at [2.28].
} 
everything it wanted from the Bill, and an amendment to include text in the offence as well as photographs was defeated. ${ }^{45}$

Section 1 of the 1978 Act (as originally enacted) provided that it is an offence 'to take, or permit to be taken, any indecent photograph of a child'. The provision also includes offences of distributing or showing such images (or having the image in one's possession with a view to showing or distributing it), and publishing an advertisement for the distribution or showing of such images. There are defences for the distribution and showing offences where the person had a 'legitimate reason' or had not seen the photos and had no reason to suspect them to be indecent. However, those defences do not apply to the 'taking' offence.

The types of case that are now prosecuted under the 1978 Act are a far cry from the traditional obscenity law cases, and the Act is primarily concerned with the protection of children from abuse and exploitation. The offence is nonetheless related to obscenity law and the term 'indecent' is drawn from the common law. ${ }^{46}$ Gillespie writes that the standard of 'indecency' is drawn from the same scale as obscenity, although the threshold for indecency is set at a lower level. ${ }^{47}$ Standards of obscenity and indecency similarly draw on contemporary standards when applied in court. Gillespie also argues that the derivation of the statutory language from obscenity law explains why the courts take an objective approach to images under the 1978 Act, in which an image is either regarded as indecent or not, rather than looking at the use of the image or the context in which it is held. ${ }^{48}$

The enactment of the Protection of Children Act 1978 was a result of the political climate in the 1970s and an offshoot of concerns about obscenity related issues more generally. The legislation was a product of moral campaigners, media publicity and a class of politicians that had little incentive to oppose the demands being made. While there was little opposition in Parliament, the association with Mary Whitehouse maybe explains why the law was viewed skeptically as unnecessary legislation by some quarters in its early years. Despite this inauspicious start, the legislative provision has been transformed with a dramatic rise in its usage. Far from being an unnecessary addition to the laws, the 1978 Act appears to be the first port of call for prosecutors and has rendered the older laws on obscenity a mere background 'safety net' provision.

\footnotetext{
${ }^{45}$ Sir Bernard Braine sought to introduce an amendment (14 July 1978).

${ }^{46}$ Knuller (Publishing, Printing and Promotions) Ltd $v$ Director of Public Prosecutions [1973] AC 435, Lord Reid stated at 458 that the term indecency refers to 'anything which an ordinary decent man or woman would find to be shocking, disgusting and revolting'.

${ }^{47}$ See A. Gillespie, 'Legal Definitions of Child Pornography' (2010) 16 Journal of Sexual Aggression 19 at 27, citing $R v$ Stanford [1972] QB 391.

${ }^{48}$ Gillespie, $\mathrm{n} 47$ above at 29.
} 


\section{Convictions under s.1 of the Protection of Children Act 1978}

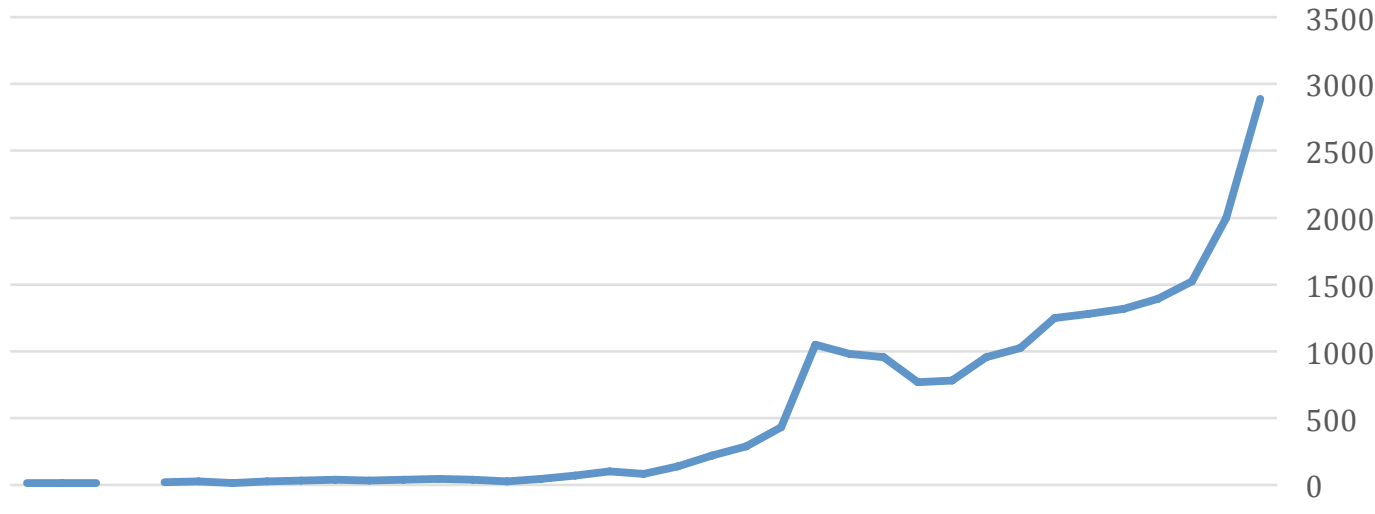

1980198219841986198819901992199419961998200020022004200620082010201220142016

There are several important developments in the legislation and its interpretation that help to explain this increase in usage. The provision has been modified and expanded on several occasions. The Criminal Justice and Public Order Act 1994 amended the 1978 Act to include 'pseudo images' within the terms of the offence. A pseudo image is, however, not something that will normally be 'taken' with a camera, but will be made either via a computer or through composite images. ${ }^{49}$ Consequently, it become necessary to further amend the 1978 Act to make it an offence 'to make', as well as 'take', an indecent image of a child. The 1994 Act further amended the law so that a photograph includes 'data stored on a computer disc or by other electronic means which is capable of conversion into a photograph'. ${ }^{50}$ The extension of the law to 'pseudo photographs' raises significant issues of principle about the nature of harm at stake, if no child has been involved in the production and if no real child is depicted in the image ${ }^{51}$ However, the extension of the offence to the 'making' of an image and to computer data has arguably been of greater significance in the long term as a result of the way the law has been interpreted.

Two decisions highlight the way the 'making' offence has expanded the reach of the law. In Atkins, the court found that intentionally storing data from the internet on a computer constituted the 'making' an image. ${ }^{52}$ However, 'making' did not include unintentional copying (for example, where the data is automatically stored on a computer cache). ${ }^{53}$ In Jayson, the Court of Appeal found that opening an email attachment could constitute the making of an image, if done with the knowledge that it contains or is likely to contain an indecent image of a child. ${ }^{54}$ The Court went further and held that 'the act of voluntarily downloading an indecent image from a web page on to a computer screen is an act of making a photograph or pseudo-

\footnotetext{
${ }^{49}$ See Home Affairs Committee. Computer pornography (HC 126) at [11-14].

${ }^{50}$ Protection of Children Act 1978, s.7 (as amended).

${ }^{51}$ For discussion of these issues, see A. Gillespie, Cybercrime (Routledge, 2015) p.248.

${ }^{52} R v$ Atkins [2000] 1 W.L.R. 1427 at 1438. See also $R v$ Bowden [2001] Q.B. 88.

${ }^{53} R v$ Atkins [2000] 1 W.L.R. 1427 at 1438.

${ }^{54} R v$ Jayson [2002] EWCA Crim 683 at [19-20]. That element of the mens rea does not apply where the offence concerns the direct filming or photography of a child, see $R v P W$ [2016] EWCA Crim 745; [2016] 2 Cr. App. R. 27.
} 
photograph. ${ }^{55}$ The offence is thereby committed if the image is knowingly called up onto the screen for a second, as the image has still been made for those brief moments. ${ }^{56}$ As a result of these decisions, the authorities were able to move their attention away from the producers of the illegal content to those viewing the images. This partly explains the increase in prosecutions under the 1978 Act, as the audience for content can normally be expected to exceed the number of producers. By changing the focus in this way, there are more targets for the law and it is unsurprising the number of people convicted has increased.

The current use of the Act contrasts with the rationale for the law when it was first enacted, which was to 'punish those who take photographs of people under 16 for indecent purposes' ${ }^{57}$ It was not enacted to penalize those who view or possess material. Suzanne Ost's work on the subject shows that in 1978 the Callaghan Government rejected proposals to criminalise the possession of indecent images of children on the grounds that it would constitute an 'inroad into private behaviour' ${ }^{58}$ On this issue, it is interesting to note the comments of Baroness Faithful, who introduced the Protection of Children Bill into the House of Lords, that people possessing the material should be treated with "compassion rather than outright condemnation', and that that one 'must try to understand the causes to eradicate such activities'. ${ }^{59}$ Similarly, Lord Longford argued that the viewers of such images should be thought of as 'ill' and deserve 'compassion'. ${ }^{60}$ These statements from the Act's supporters are a far cry from the current usage of the offences under the Act.

There are concerns that the definition of 'making' an image could criminalise those that inadvertently receive images, for example through pop-ups when visiting adult websites. In Harrison, the defendant was convicted in relation to images on pop-up advertisements, with Cranston $J$ stating that a person has sufficient knowledge to commit the offence if they knew that that a pop-up was likely to appear and that there was a likelihood that it would contain an illegal image. ${ }^{61}$ Gillespie describes this decision as 'an extension too far' in so far as the individual user has no control over whether a pop-up appears and may well be seeking to view lawful content. ${ }^{62}$ The decision follows the logic of the reasoning in Jayson, but it shows how the law is gradually extending its reach to those with a more remote connection with the harm targeted by the Act.

Another concern relates to the uncertainty of the indecency standard and the types of content that can be caught by the provision. In many cases the question of indecency will be clear, but there are borderline cases. ${ }^{63}$ During the parliamentary debates in 1978, concerns were expressed about the term 'indecent' and some MPs and peers sought reassurance that it would not criminalise an innocent photograph taken by a parent or grandparent. The question of certainty becomes more pressing when applied

\footnotetext{
${ }^{55} R$ v Jayson [2002] EWCA Crim 683 at [33].

${ }^{56} R$ v Jayson [2002] EWCA Crim 683 at [33].

${ }^{57}$ Brynmor John, HC Deb 14 July 1978, vol 953 col 954.

${ }^{58}$ Quoting the government minister Brynmor John, see S. Ost, Child Pornography and Sexual Grooming (Cambridge University Press, 2009), p.60 at footnote 40.

${ }^{59}$ HL Deb, 5 May 1978, vol 391, cols 539-540.

${ }^{60}$ HL Deb, 5 May 1978, vol 391, col 568.

${ }^{61} R v$ Harrison [2007] EWCA Crim 2976, [2008] 1 Cr. App. R. 29 at [19].

${ }^{62}$ A. Gillespie, Child Pornography: Law and Policy (Routledge, 2011), p.125-26.

${ }^{63}$ Ost, n 58 above.
} 
to the individual viewer who may be less familiar with the law and have fewer resources to navigate the legal controls. The court has nonetheless found that the term indecent is sufficiently foreseeable to fulfil the requirements of the ECHR. ${ }^{64}$ The court has, however, found that targeting the viewer is not appropriate where material is widely available through mainstream retailers and where the authorities can easily target a publisher or distributor. ${ }^{65}$ The producers of the content should be normally take on greater responsibility.

The law has not remained static since Jayson and the Act has been expanded through legislative amendment. In 2008, the 1978 Act was amended so that the term 'photograph' includes a 'tracing or other image' that 'is derived from the whole or part of a photograph or pseudo-photograph' ${ }^{66}$ That also provides another tool for police and prosecutors, preventing the law from being evaded through the tracing of photographic images.

The increased usage of the 1978 Act is most likely explained by the changes in definition and interpretation alongside the developments in technology. The upward number of convictions in the late 1990s is in line with the general growth of internet access and with digital imaging more generally. This means that potentially more offences may have been committed, given the ease of accessing content over the internet. The increased usage of s. 1 in 2003 can be attributed to the number of cases generated from Operation Ore that began in 2002 to look into over 7,000 people in the UK that had paid to access to a US based website that hosted indecent images of children. ${ }^{67}$ The increase in the use of cautions in 2003 may also reflect the increased burden on the police following Operation Ore.

What is also striking is that in earlier discussions of the statistics, the spike in 2003 was regarded as a temporary high on account of Operation Ore. ${ }^{68}$ However, 2010 saw a higher number of prosecutions and conviction than 2003. The number of convictions has increased each year and in 2016 the figure reached 2890, with a further 185 cautions issued. It is difficult to know what has caused this steady increase in more recent years. One factor might be that the police are better equipped to deal with such cases and know how to collect the relevant evidence. The changes in technology means that it is not only easier for people to access such content, but also to be detected, which also increases the number of people that can be brought before the law. It is also interesting to note that while the number convictions has increased dramatically in the last decade, the number of cautions has remained relatively stable in the same period and has not exceeded the high of 239 since 2003.

To summarise, the 1978 Act was once seen by some as possibly an unnecessary addition that provided a new tool to supplement the Obscene Publications Act 1959. The statistics show that the use of the Obscene Publications Acts has long been

\footnotetext{
${ }^{64} O^{\prime}$ Carroll $v$ United Kingdom (2005) 41 E.H.R.R. SE1, and R. v O'Carroll (Thomas Victor) [2003] EWCA Crim 2338.

${ }^{65} R v$ Neal [2011] EWCA Crim 461, quashing a conviction under the possession offence in relation to a book containing photographs by David Hamilton, Sally Mann and Jock Sturges.

${ }^{66}$ Protection of Children Act 1978, s.7(4A), inserted by the Criminal Justice and Immigration Act 2008.

${ }^{67}$ Ost, $\mathrm{n} 58$ above, p.92.

${ }^{68}$ Ost, n 58 above, p.92.
} 
overtaken by the 1978 Act. As a result, the 1978 Act is now the primary tool used in relation to obscene-related content. By targeting the viewer, a vastly broader range of actors are subject to the 1978 Act controls. The statute overlaps with the 1959 Act, but is much narrower in scope as it applies only to images of children. The increased uptake in using the 1978 Act and the relative decline in the use of the Obscene Publications Act 1959 thereby reflects a policy decision to concentrate resources on the protection of children, rather than on obscenity more generally.

\section{Possessing indecent images of children}

The 1978 Act is not the only offence concerned with indecent images of children. In 1988, the government tabled an amendment to the Criminal Justice Act 1988 to introduce a new offence of possessing indecent images of children. Unlike the 'making' or 'taking' offence under the 1978 Act, the possession offence under s.160 of the 1988 Act provides that it is a defence where the person had a 'legitimate reason' for having the image. It is also a defence if the person had not seen the image and had no reason to suspect that it was indecent, or that the image had been sent to the defendant without prior request and that he did not keep it for an unreasonable time. The possession offence was created prior to the introduction of the 'making' offence under the 1978 Act and the decisions in Atkins and Jayson (discussed above). The s. 160 possession offence thereby marked the first step in a shift towards targeting the recipient rather than the producer of the material.

When the offence was first introduced, the main rationale advanced was that punishing possession would dry up the demand that caused the images to be produced in the first place. ${ }^{69}$ The then Home Secretary Douglas Hurd stated in Parliament that it was 'justified to criminalise simple possession in the hope of stamping out this degrading trade. ${ }^{70}$ Another argument was that the content itself is likely to influence behaviour and make certain people more likely to commit acts of abuse. Along these lines, the Minister of State, John Patten stated to the press that a criminal measure was necessary partly because the images 'fed the instincts which gave rise to sexual abuse'. ${ }^{71}$

The legislation was also a response to the demands from the police that new powers were necessary. ${ }^{72}$ The Minister of State noted that the police had uncovered the possession of indecent images of children when raiding suspected paedophiles, but could take no action where there was no evidence of the person being involved in the production of the image or the abuse of any child. ${ }^{73}$ The argument therefore ran that the 'taking' offence under the 1978 Act was not enough. That argument, however, takes it as a given that such people should be subject to criminal sanction where there is no involvement in the production of an image. That argument thereby falls back on the other rationales to explain why possession should be criminalised in the first place.

\footnotetext{
${ }^{69}$ The Guardian, 'New penalty to curb child porn' 1 March 1988.

${ }^{70}$ Douglas Hurd, HC Deb, 18 Jan 1988, vol 125, col 689.

${ }^{71}$ The Guardian, 'New penalty to curb child porn' 1 March 1988.

72 The Times, 'Obscenity Call', 8 October 1987, noting that the Scotland Yard Officer Ian Donaldson had called for a possession offence.

${ }^{73}$ The Guardian, 'New penalty to curb child porn' 1 March 1988.
} 
There are other arguments that can be advanced to support such a measure. ${ }^{74}$ The viewing of an indecent image of a child can perpetuate the harm and suffering caused to the person depicted. The argument runs that the viewer needs to take some responsibility for the consequences of their actions in perpetuating the harm. Another argument is that the content can be used as a tool in the process of grooming children. However, such a concern could be more directly addressed by criminalising the grooming of children and showing of images to them. ${ }^{75}$ Finally, in public debate, there is often a general sense that possession of the material is a form of deviant behaviour in itself that should be punished regardless of whether any other harm occurs. Such an argument has a more moralistic element to it and plays a more central role in justifications for criminalising pseudo images that do not depict a real child.

The statistics show a similar pattern to the 1978 Act offences, in so far as there is an increase in convictions from 2003 that can partly be explained by the results of Operation Ore and also with the increase in high-speed internet connections more generally. What is also noticeable is that since 2011, the previous record number of convictions from 2003 was exceeded and has continued to rise since. The number of convictions under s.160 also exceeded those under the Obscene Publications Act for the first time in 1999, and has done so each year since 2002 by a significant number.

While s.160 may have filled a gap in the law when enacted, the subsequent developments in the interpretation of the 1978 Act discussed above have generated significant overlap in the law and potential for confusion. A person who views illegal content and has it stored on the computer cache will likely commit an offence under both s.160 and the 1978 Act. As a result, prosecutors will often have a choice between offences in relation to the viewing of images. The 1978 Act has a higher burden in terms of mens rea, to show that the defendant knew the image was or was likely to be an indecent image of a child. However, s.160 also has a wider range of defences available, which may encourage the prosecutors to rely on the 1978 Act. Ost writes that the effect of the decisions in Atkins and Jayson has been to 'merge' the offences of 'possession' and 'making' of an image. ${ }^{76}$

\section{Prohibited images}

Subsequent legislation has introduced further possession offences. The Coroners and Justice Act 2009 introduced a new offence of possessing a 'prohibited image'. Under the Act, an image is prohibited if it is pornographic, 'is grossly offensive, disgusting or otherwise of an obscene character' and either 'focuses solely or principally on a child's genitals or anal region' or portrays certain acts listed in the provision. The provision does not apply to photographs or pseudo photographs, but instead was enacted to deal with the problem of drawings or cartoons that depict children and certain sexual activities, though the cartoon need not depict a child being engaged in the sexual activity itself. ${ }^{77}$ As with other changes to the law, the provision was

\footnotetext{
${ }^{74}$ For discussion of these rationales see Gillespie, $n 62$ above, pp.33-39.

${ }^{75}$ Gillespie, n 62 above, p.109, discussing virtual images.

${ }^{76}$ Ost, n 58 above at p.60.

${ }^{77}$ For example, the list of acts referred to in the statute includes 'the performance by a person of an act of intercourse or oral sex with or in the presence of a child'.
} 
prompted by the frustration of police officers when raiding suspected paedophiles, finding evidence of a sexual interest in children (such as cartoon images) and being able to take no legal action against those individuals. ${ }^{78}$ The provision has provoked controversy, particularly in relation to the rationale for criminalisation and lack of harm to an actual child in relation to the offence. ${ }^{79}$ While the offence targets relatively specific types of content, it can be connected to the law of obscenity, particularly as the provision includes the term 'obscene character' in the formula for a prohibited image. So far, the provision has had relatively low usage. In 2015, there were 24 convictions under this offence. The low number is possibly unsurprising, and in many cases the people possessing such images (and who come to the attention of the authorities) may be likely to have viewed or to possess other types of unlawful content. As result, many people possessing prohibited images will be convicted of other more serious offences discussed earlier (which will be recorded as the principal offence in the statistics).

\section{Possession of extreme pornography}

The final criminal offence to be considered is another possession offence, this time relating to extreme pornography under s.63 of the Criminal Justice and Immigration Act 2008. Under the s.63 offence, an image is pornographic if it is 'of such a nature that it must reasonably be assumed to have been produced solely or principally for the purpose of sexual arousal.' To be 'extreme' the image must be ' grossly offensive, disgusting or otherwise of an obscene character' and portray 'in an explicit and realistic way' one of the following:

(1) 'an act which threatens a person's life',

(2) 'an act which results, or is likely to result, in serious injury to a person's anus, breasts or genitals';

(3) 'an act which involves sexual interference with a human corpse' or

(4) 'a person performing an act of intercourse or oral sex with an animal (whether dead or alive)'.

(5) 'an act which involves the non-consensual penetration of a person's vagina, anus or mouth by another with the other person's penis' or

(6) 'an act which involves the non-consensual sexual penetration of a person's vagina or anus by another with a part of the other person's body or anything else'. ${ }^{80}$

The offence also requires that in all these categories, 'a reasonable person looking at the image would think that any such person or animal was real'. ${ }^{81}$

The offence of possessing extreme pornography was enacted as a result of a campaign following the murder of Jane Longhurst and the discovery that her killer Graham Coutt's had watched violent pornography prior to committing the crime. Following Coutt's conviction, the victim's mother Liz Longhurst called for greater controls on extreme and violent content, stating that 'political pressure should be brought to bear

\footnotetext{
${ }^{78}$ Home Office, Consultation on Possession of Non-Photographic Visual Depictions of Child Sexual Abuse (2007), p.4.

${ }^{79}$ S. Ost, 'Criminalising fabricated images of child pornography: a matter of harm or morality?' (2010) 30 Legal Studies 230.

${ }^{80}$ The material under (5) and (6) were added to s.63 by the Criminal Justice and Courts Act 2015.

${ }^{81}$ Criminal Justice and Immigration Act 2008 s.63.
} 
on internet service providers to close down or filter out these pornographic sites'. ${ }^{82}$ Her cause was taken up by her MP Martin Salter, who sponsored an Early Day Motion in February 2004 supporting the call for action to be taken to close down the sites and conduct a review of the Obscene Publications Acts. ${ }^{83}$ The call to action was later elaborated in a five point action plan that was put to the Home Office, which included the consideration of a new possession offence. ${ }^{84}$ The MPs Martin Salter and David Lepper also presented a petition of over 50,000 signatures supporting the plan to the Home Office. ${ }^{85}$ The government responded in 2005 with a proposal to enact an offence of possessing extreme pornography, taking its inspiration from the offence of possessing indecent images of children, and launched a public consultation. ${ }^{86}$

The prominence of the Longhurst murder in the campaign meant that the debates surrounding the enactment of the new offence often centred on whether the extreme content caused harm by influencing behaviour and whether that justified further criminal restriction. In the initial consultation on the possession offence, the government found the research on the effect on the reader to be inconclusive ${ }^{87}$ Such a conclusion is unsurprising, given that it will be difficult to identify the main influences on a person's thought processes. To demand such concrete evidence that content influence behavior would set a very high threshold before the state can act. The potential harm of extreme content need not be cast in terms of direct effects on audience behavior. McGlynn and Rackley argue that a possession offence should be premised on the 'cultural harm' caused by such material, in so far as such material creates a climate that encourages or legitimises violent sexual activity. ${ }^{88}$

Nonetheless, the government sought to engage with questions about the direct effects of such content and commissioned a rapid evidence assessment to examine the research relating to the possible harms of exposure to extreme pornography ${ }^{89}$ Once published, the research was relied on in parliamentary debates, with Lord Hunt stating that the research undertaken for the assessment 'indicates that such material may have harmful effects on some people, in particular those with a history of sexual and other aggression'. ${ }^{90}$ Rather than resolving any issues, the report divided opinion. For example, Smith and Attwood criticised the assessment on a number of grounds, including that old research (conducted prior to mass internet usage) was relied in the analysis, that the content subject to the research did not map onto the extreme material

\footnotetext{
82 'Killer was obsessed by porn websites', The Guardian, 5 February 2004.

${ }^{83}$ Early Day Motion 583 (2004), 'Murder of Jane Longhurst and Internet Sites Promoting Necrophilia', supported by 169 MPs.

${ }^{84}$ HC Deb, 18 May 2004, vol 421, col 170WH.

${ }^{85}$ David Lepper MP, HC Deb, 8 October 2007, vol 464 cols 91-92

${ }^{86}$ Home Office, Consultation: On the possession of extreme pornographic material (2005).

${ }^{87}$ Ibid at [31].

${ }^{88}$ C. McGlynn and E. Rackley, 'Criminalising extreme pornography: a lost opportunity' (2009) Criminal Law Review 245 at 257.

${ }^{89}$ C. Itzin, A. Taket and L.Kelly, The evidence of harm to adults relating to exposure to extreme pornographic material: rapid evidence assessment (Ministry of Justice Research Series, 2007).

${ }^{90}$ Lord Hunt, HL Debate 3 March 2008, vol 699, col 893GC and 907GC. See also Martin Salter MP, HC Deb, 8 October 2007, vol 464, col 93. Maria Eagle MP Criminal Justice and Immigration Bill Deb, 16 October 2007, col 31, stating that the research 'showed that there was cause to have concern in certain circumstances for what is, no doubt, a smallish number of the population who might be susceptible to their behaviour being affected by viewing extreme pornography.'
} 
prohibited under the possession offence, and that the studies relied upon in the report were cautious about the research being used to justify stricter legal controls. ${ }^{91}$

Direct harm was not the sole argument advanced to justify an offence of possessing extreme pornography. At other times, the rationale for the measure seemed to be based on the moral judgment that such content should not be viewed. For example, in the initial consultation, the government stated that whatever the evidence of harm, the possession of extreme images should be prohibited on the grounds that it has 'no place in our society'. ${ }^{92}$ Such arguments were also controversial. In the parliamentary debates, concern was expressed that certain types of image might be criminalized not on the basis of any harm, but simply on the grounds of moral disapproval. ${ }^{93}$ The Bishop of Chester expressed reservations that the offence was simply being enacted on the basis 'that this is what most people do not like'. ${ }^{94}$ The government sought to address this concern in a number of amendments in the House of Lords, limiting the offence only to content that is explicit and realistic. ${ }^{95}$ The government also pointed out that the offence was limited by the clause requiring the material to be grossly offensive, disgusting or otherwise of an obscene character and therefore did not criminalise material that would not be liable under the Obscene Publications Act $1959 .{ }^{96}$ While attempting to limit the reach of the offence, incorporating a standard relying on the language of obscenity and disgust left the government open to the criticism that the provision applies moralistic standards. ${ }^{97}$

The government's point that the material caught by the possession offence was already criminalised under the existing law of obscenity allowed the measure to be presented as a pragmatic update of the law in the digital era. The argument ran that it is not possible to impose a penalty on the publishers or producers of extreme material that are based overseas, so a more effective strategy is to target the demand of such material from those based within jurisdiction. ${ }^{98}$ In the House of Lords, Lord Hunt stated that the law is 'not trying to change the position on what types of material we should accept as permissible in our society'. ${ }^{99}$ The presentation of the measure as a more pragmatic update to the law downplayed the significance of the shift in regulating the possessor rather than the publisher of the material.

In the parliamentary debates, some contributions discussed the implications of the shift to an offence based on possession. ${ }^{100}$ Baroness Miller noted that the offence

\footnotetext{
${ }^{91}$ F. Attwood and C. Smith, 'Extreme Concern: Regulating 'Dangerous Pictures' in the United Kingdom' (2010) 37 Journal of Law and Society 171 at 174-176. See also Baroness Miller, HL Deb, 22 Jan 2008, vol 698, col 151.

${ }^{92}$ At [11] and [27].

${ }^{93}$ Criminal Justice and Immigration Bill Deb, 18 October 2007, c124, looking at the application of the offence to extracts from classified films that depict scene of sexual violence.

${ }^{94}$ HL Deb, 3 March 2008, vol 699, col 908GC.

${ }^{95}$ Joint Committee on Human Rights, Legislative Scrutiny: Government Replies (2008, HL 126/ HC755) Appendix 2, Letter from the Rt Hon David Hanson MP at [49-57].

${ }^{96}$ Lord Hunt, HL Deb, 3 Mar 2008, vol 699, col 895GC.

${ }^{97}$ McGlynn and Rackley, n 88 above, at 252.

${ }^{98}$ Martin Salter MP, a leading figure in the campaign for the offence, HC Deb, 8 October 2007, vol 464, col 111. Lord Hunt, HL Deb, 3 Mar 2008, vol 699, col 894GC and 910GC.

${ }^{99}$ See Lord Hunt, HL Deb, 3 March 2008, vol 699, col 893GC.

${ }^{100}$ For an account of the parliamentary debate and the various concerns expressed about the offence, see A. Murray, 'The Reclassification of Extreme Pornographic Images' (2009) 72 Modern Law Review 73.
} 
allows the police to intervene before a person viewing the material has committed a crime or other harmful act. ${ }^{101}$ She noted that the life of such a person is likely to be ruined and that such intervention 'is truly the domain of the thought police'. ${ }^{102}$ Baroness Miller also warned that the shift to a possession offence meant that the individual receiving the images would have to make an assessment of whether the material was lawful, and wondered whether the offence was sufficiently certain to guide the conduct of a viewer. ${ }^{103}$

The government's response to such concerns was that the definition of extreme pornography is more detailed than the 'deprave and corrupt' standard found in the Obscene Publications Act 1959, and thereby provides clearer guidance to the individual. ${ }^{104}$ However, approaching the issue from a different angle, the tighter definition of the prohibited material has left the measure open to criticisms of underinclusiveness. Rackley and McGlynn argue that the attempt to provide a tighter definition of extreme content led to the exclusion of depictions of acts that injure body parts other than the anus, breasts or genitals. ${ }^{105}$ The issue illustrates how in attempting to mediate between the competing pressures, the government ended up pleasing nobody. In relation to the charge of under-inclusiveness, the offence was further amended in 2015 to include non-consensual images of penetration, to ensure that images of rape were caught by the offence.

At the Third Reading in the House of Lords Lord Hunt stated that the the purpose of the law is simply to provide 'an additional tool to deal with individuals whose behaviour may be causing concern'. ${ }^{106}$ However, such an additional tool can provide police and prosecutors with a level of discretion that is open to abuse or may generate feelings of unfair use. Baroness Miller noted that the offence is most likely to be enforced against those that are subject to 'concern' from the police and get raided for whatever reason. ${ }^{107}$ Along similar lines, another criticism of the offence is that it can criminalise the depiction of certain consensual activities that are targeted by the authorities, and that the BDSM community may be vulnerable to prosecution. ${ }^{108}$ For example, in 2012 a man was acquitted of charges relating to images of fisting and urethral sounding. ${ }^{109}$ While such prosecutions may be relatively rare and unrepresentative of most uses of the possession offence, ${ }^{110}$ such examples are still troubling in showing how the law can be used against certain minority groups.

Critics of the s.63 offence argue that it is sometimes used as fall-back option. In many cases, the people prosecuted under s.63 will also be charged with offences relating to

\footnotetext{
${ }^{101}$ HL Deb, 30 Apr 2008, vol 701, col 263.

${ }^{102}$ HL Deb, 30 Apr 2008 vol 701, col 263. For a similar criticism see A. Nair, 'Real porn and pseudo porn: The regulatory road' (2010) 24 International Journal of Law and Information Technology 223 at p.231.

${ }^{103}$ Baroness Miller, HL Deb, 22 Jan 2008 vol 698, col 151. In the same debate, the Earl of Onslow also questioned whether the standards in the offence met the conditions of foreseeability.

${ }^{104}$ Lord Hunt, HL Deb, 3 Mar 2008, vol 699, col 894GC.

${ }^{105}$ McGlynn and Rackley, n 88 above, at 249-250. Gillespie, n 51 above, p.217.

${ }^{106}$ HL Deb, 30 April 2008, vol 701, col 271.

${ }^{107}$ HL Deb, 30 Apr 2008, vol 701, col 274.

${ }^{108}$ Though s.66 provides a defence where the image is of the defendant participating in consensual activities.

109 'Jury acquits barrister in "extreme porn” case' The Guardian, 9 August 2012.

${ }^{110}$ C. McGlynn and E. Rackley, 'Prosecuting the possession of extreme pornography: a misunderstood and mis-used law’ [2013] Criminal Law Review 400 at 404.
} 
images of children. ${ }^{111}$ However, the criticism runs that the police sometimes raid a person in relation to one crime and discover no evidence of that primary crime, but incidentally discover extreme pornographic material that provides the basis for a prosecution. ${ }^{112}$ The criticism is that the possession offence is sometimes used when the real concern of the authorities is with the suspected commission of a different crime.

As the offence was being enacted, the Ministry of Justice stated that the law would be used only in the more extreme cases. ${ }^{113}$ Despite that assurance, the statistics show that the use of the offence is not rare, with 121 convictions in 2016. The more detailed breakdown of the conviction statistics is also revealing, with the vast majority of convictions relating to images of bestiality. Of the convictions in 2015, 105 were for the possession of a person performing an act of intercourse or oral sex with an animal, and in 2016 the number of convictions rose to $112 .{ }^{114}$ By contrast, in 2016 only one conviction was for the possession of an extreme pornographic image portraying rape, and four convictions were for possession of an act which is likely to result in serious injury to a person's anus, breasts or genitals. Such lower numbers may be surprising, given that the concern with images of rape and sexual violence lay at the heart of the initial justification enacting the offence.

Moreover, some prosecutions seem hard to square with an assurance that only the extreme cases will be prosecuted. For example, a 39-year old man was prosecuted for the offence after a film depicting sexual acts between a woman and a dog was sent to the defendant's mobile phone. ${ }^{115}$ The film was sent unsolicited and the defendant mistakenly believed that he had deleted it. He later inadvertently transferred the undeleted file to his computer while transferring music files from his mobile phone. The Court of Appeal reduced his sentence of 100 hours unpaid work in the community to a conditional discharge, stating that 'the only culpability on the part of the appellant was that he did not check his mobile to ensure that he had in fact deleted the film'. ${ }^{116}$ Despite the reduction in sentence, the individual concerned (having pleaded guilty following legal advice) was still subject to a criminal conviction. The example shows how the offence is framed in a way that can lead to questionable prosecutions and criminalise those who did not wish to view the material and pose little harm to others.

\section{Alternatives to the criminal law}

A focus on the criminal convictions gives a limited picture and examines only one strategy for combatting concerns about obscene publications and related issues. As

\footnotetext{
${ }^{111}$ A. Nair and J. Griffin, 'The regulation of online extreme pornography: purposive teleology (in) action' (2013) International Journal of Law and Information Technology 329, describe the offence as an 'add-on', citing $R v$ Clark [2012] EWCA Crim 1707 as an example.

${ }^{112}$ E. Docx 'One lawyer's crusade to defend extreme pornography' The Guardian 16 October 2015.

113 'Battle lines drawn over Bill to ban 'extreme' porn', The Guardian, 30 December 2008. Lord Hunt, HL Deb, 30 April 2008, vol 701, col 271.

${ }^{114}$ Ministry of Justice, Criminal Justice System Statistics Quarterly: December 2016 (May 2017).

${ }^{115} R v$ Sharples [2012] EWCA Crim 3144. For discussion of another example, see E. Docx 'One lawyer's crusade to defend extreme pornography' The Guardian 16 October 2015.

116 The court found that there was no basis to doubt what the appellant claimed on the facts, $R v$ Sharples [2012] EWCA Crim 3144 at [8].
} 
noted earlier, the powers of forfeiture under s.3 of the Obscene Publications Act 1959 provided a practical control on the circulation of obscene content. Those powers were used far more widely than the power to prosecute under s.2 of the 1959 Act and represents a central control on obscene content. Those methods of control are less effective in the case of data, but are supplemented by new methods that have been developed to control the dissemination of unlawful content online. Most obviously, broadband providers in the UK operate a system for blocking illegal content, primarily indecent images of children, which is facilitated by the Internet Watch Foundation (a self-regulatory body). ${ }^{117}$ A system of blocking aims to stop unlawful material being accessed by potential viewers.

Other tools are being developed to curb the flow of content in the name of protecting children from being exposed to adult material. The providers of video on-demand services in the UK are now subject to an equivalent of the film classification system and should not provide access to material that would not be granted a certificate by the BBFC. ${ }^{118}$ The Digital Economy Act 2017 requires those providing lawful adult content on a commercial basis to operate a system of age verification to allow access to the sites. ${ }^{119}$ The leading broadband providers also present subscribers with an 'unavoidable choice' whether to use filters to screen out adult content. ${ }^{120}$ To some degree, these measures may be seen as extending strategies from the offline world, such as age restrictions on purchasing certain magazines or films, to digital communications. However, the critics argue that these measures raise issues for the privacy of adults that wish to access lawful content. There is, however, a trade off, as such measures do not impose criminal liability on the viewer and targets those further up in the chain of distribution.

For present purposes, the central point is that new controls are emerging to deal with the old obscenity related concerns of the young being 'corrupted'. The transformation of obscenity law has arisen through a range of techniques that mark a shift away from the classic publication offences. The old obscenity cases tended to revolve around issues of artistic freedom, which tend to be less prominent in contemporary cases. The free speech issues have, however, changed rather than gone away. The newer controls raise issues of surveillance, privacy and the rights of people to receive content, which are themselves significant constitutional matters touching on the relationship between citizen and state. More broadly, the issues are important as the techniques developed to combat problems of pornography can adapted to deal with other legal problems. For example, the system used for blocking unlawful images of children has been adapted and applied to protect intellectual property rights. ${ }^{121}$ Similarly in Mosley $v$ Google, the fact that technology existed to block identified indecent images of children, supported the court's refusal to dismiss a legal action asking intermediaries to block or remove privacy invading photographs. ${ }^{122}$ Once a control has been developed to combat issues related to extreme types of pornography, there are 'off the peg' solutions that can be applied to protect other legal rights. The obscenity related

\footnotetext{
${ }^{117}$ See https://www.iwf.org.uk/.

${ }^{118}$ Communications Act 2003, s.368E.

${ }^{119}$ Digital Economy Act 2017.

${ }^{120}$ See Ofcom, Report on Internet Safety Measures (2015).

${ }^{121}$ See Twentieth Century Fox v BT [2011] EWHC 1981.

${ }^{122}$ Mosley v Google [2015] EWHC 59 (QB); [2015] 2 C.M.L.R. 22
} 
laws can therefore be seen as a type of testing ground for other controls on communication.

\section{Conclusion}

The article started by looking at the number of prosecutions and convictions in relation to category 86 'obscenity' offences in the Home Office and Ministry of Justice statistics. The categorisation may now seem inappropriate, as the various offences are concerned with different issues. ${ }^{123}$ Along these lines, the law of obscenity is primarily concerned with issues of morality and raised significant issues of freedom of expression and civil liberties. By contrast, the offences relating to indecent images of children are concerned with protecting children from abuse and exploitation. Under such an understanding, the law relating to images of children is better viewed as a branch of the criminal law on sexual offences, as opposed to the general obscenity offence that was a topic in the constitutional law courses.

However, the law of obscenity and the law concerning indecent images of children are still connected. The discussion has shown how the offences under the 1978 Act emerged from the cultural battles of the 1970s led by moral crusaders, who also campaigned on issues relating to obscenity law and blasphemy. The statute also draws on the language of indecency, which is a relative of obscenity. Moreover, where no actual child is involved in the production of or depicted in a pseudo image, the law arguably has a more moralistic dimension. Given the wide range of content that might be subject to the criminal offences, the law on indecent images of children can be viewed as a branch of the law of sexual offences or as an offshoot of obscenity law.

The analysis has shown that the law of obscenity has undergone a significant transformation. A central change has been the shift from the publisher (in traditional obscenity law) to the viewer of the content. This shift from publisher to audience widens the number of people that can be targets of the law, which helps to explain the increase in convictions. A second transformation is the shift away from a broad offence focusing on obscene content, to the reliance on provisions that target a narrower range of content. That explains seeming contradiction that the law has in some respects become more liberal, as content that was once illegal is now freely available, yet at the same has become much stricter and criminalising more people than ever.

The discussion has also shown how laws passed to deal with a contemporary controversy or crisis at the time can take on a new significance as circumstances change. In its earlier years, the 1978 Act appeared to be used relatively infrequently, supporting the view that it was merely supplementing the central obscenity laws. A combination of a change in standards to focus on the protection of children and the increasing availability of content online means that the 1978 Act now provides the goto offence for prosecutors. The change also shows how the practice has gradually evolved away from the original rationale of the legislation. While a sponsor of the Act argued that the viewers should be treated with compassion, this is a far cry from the

\footnotetext{
${ }^{123}$ The Home Office now lists the offences relating to images of children separately as a sub-category of obscenity related offences.
} 
current usage of the 'making' offence that is now applied routinely to the viewers. Statutes need to develop with new circumstances, so such a change is not objectionable in itself. However, it does mean that the law was framed in terms that did not anticipate the current issues subsequent developments. The evolution of the law also provides a reminder that people should be wary of assurances about the future use of legislation given at the time of enactment and that it is worth reassessing the working of the law periodically.

At various points in the discussion, a number of criticisms of the law have been mentioned. The statistics say little about whether the criticisms are well founded and the central focus of this article has been with the means of controlling content. The statistics do, however, make clear that there has been a sharp increase in the number of people brought into the criminal justice system. The criminal prosecution statistics pale into insignificance compared with some estimates of the illegal activities taking place. The Child Exploitation and Online Protection Centre estimated that 50,000 individuals in the UK downloaded or shared indecent images of children in 2012. ${ }^{124}$ If that figure is correct, then it raises questions about whether the law is having a deterrent effect, whether the criminal law can adequately deal with that number of offenders and provide a thorough and fair investigation. On this issue, the National Police Chiefs' Council lead for child protection, Simon Bailey, argued that the system was struggling to cope with the sheer number of offences. Mr Bailey called for resources to be focused on high risk offenders, and that those viewing relatively 'low level' images should not be faced with criminal prosecution, but should go through a programme of counselling and rehabilitation. ${ }^{125}$ Such comments are resonant with the views of Baroness Faithful, when introducing the Protection of Children Act 1978. It is not clear from the statistics whether the current prosecution strategy is capturing the persistent criminal that poses a clear danger to society, or whether the current prosecutions focus on the low hanging fruit that are not technologically proficient and lack the ability to cover their tracks. However, many media commentators and politicians dismissed Mr Bailey's comments or reacted with alarm. Such reactions reflect the continued criticism that the area of law lacks of critical scrutiny and that measures are sometimes railroaded through Parliament. A climate in which critical opinion is treated with hostility or misrepresented can increase the chances for flaws in the legal system to go undetected.

The transformation of obscenity law has taken place against a background of changes in technology, in which content can be freely distributed across borders and which pose significant challenges to the traditional forms of control. As a result, there are new techniques for control that are being adapted and tested, some of which go beyond criminal offences and include the filtering and blocking of content. These changes show that obscenity law continues to raise issues of constitutional significance. However, these are not the grand issues of free speech and artistic expression that often dominated the debate in the 1960s and 70s. Instead, the constitutional dimension in the contemporary obscenity law focuses on more detailed questions about the role privacy, surveillance and the responsibilities of the recipient of content. The constitutional dimension may have changed over the years, but the

\footnotetext{
${ }^{124}$ Child Exploitation and Online Protection Centre, Threat Assessment of Child Sexual Exploitation and Abuse (2013).

125 'Don't lock up low-risk paedophiles say police' The Times, 28 February 2017.
} 
area of law continues to raise central questions about the relationship between citizen and state.

\section{Appendix: Collated data from available sources}

The data has been collected from different sources and as a result there is a possibility the statistics have been collected on a different basis. The list of sources below indicates where there is a conflict in the available data. Where not otherwise stated, the statistics state that they have been collected on a 'principal offender basis'. The sources have also been marked in the following way to show any statements about the way the data has been collected:

* The source states that the data includes persons proceeded against in earlier years or for other offences.

** The source does not specify whether the statistics are on a principal offence basis.

Table 1: Convictions and Cautions for Indictable Offences under Category 86 in England and Wales

\begin{tabular}{|r|r|r|r|}
\hline Year & \multicolumn{2}{|l|}{$\begin{array}{l}\text { Convictions and } \\
\text { Cautions }\end{array}$} & $\begin{array}{l}\text { Year } \\
\text { and Cautions }\end{array}$ \\
\hline 2016 & 4180 & 1997 & 510 \\
\hline 2015 & 3122 & 1996 & 529 \\
\hline 2014 & 2448 & 1995 & 489 \\
\hline 2013 & 2368 & 1994 & 350 \\
\hline 2012 & 2263 & 1993 & 312 \\
\hline 2011 & 2229 & 1992 & 282 \\
\hline 2010 & 1919 & 1991 & 302 \\
\hline 2009 & 1,728 & 1990 & 210 \\
\hline 2008 & 1,641 & 1989 & 191 \\
\hline 2007 & 1,414 & 1988 & 301 \\
\hline 2006 & 1,358 & 1987 & 200 \\
\hline 2005 & 1,605 & 1986 & 168 \\
\hline 2004 & 1,628 & 1985 & 286 \\
\hline 2003 & 1,769 & 1984 & 481 \\
\hline 2002 & 794 & 1983 & 406 \\
\hline 2001 & 547 & 1982 & 266 \\
\hline 2000 & 508 & 1981 & 236 \\
\hline 1999 & 438 & 1980 & 174 \\
\hline 1998 & 437 & 1979 & 114 \\
\hline & & & \\
\hline
\end{tabular}

Sources:

Home Office, Criminal Statistics, England and Wales 1986 (1987, Cm 233) Table 5.20 (for 19791986).

Home Office, Criminal Statistics, England and Wales 1997 (1998, Cm 4162) Table 5.18 (for 19871997).

Ministry of Justice, Criminal Statistics, England and Wales 2007 (2008) (for 1998-2007). 
Ministry of Justice, Criminal Justice System Statistics Quarterly: December 2016 (May 2017) (for 2006-2016).

Table 2: Prosecutions and Convictions under the Obscene Publications Act 1959 in England and Wales

\begin{tabular}{|l|l|l|}
\hline & Prosecuted & Convicted \\
\hline 2016 & 4 & 5 \\
\hline 2015 & 0 & 2 \\
\hline 2014 & 10 & 10 \\
\hline 2013 & 3 & 5 \\
\hline 2012 & 4 & 3 \\
\hline 2011 & 2 & 3 \\
\hline 2010 & 7 & 7 \\
\hline 2009 & 14 & 19 \\
\hline 2008 & 24 & 23 \\
\hline 2007 & 32 & 21 \\
\hline 2006 & 29 & 18 \\
\hline 2005 & 35 & 35 \\
\hline 2004 & 30 & 25 \\
\hline 2003 & 39 & 31 \\
\hline 2002 & 52 & 42 \\
\hline 2001 & & \\
\hline 2000 & & 81 \\
\hline 1999 & & 96 \\
\hline 1998 & & 176 \\
\hline 1997 & & 186 \\
\hline 1996 & 335 & 262 \\
\hline 1995 & 357 & 259 \\
\hline 1994 & 309 & 266 \\
\hline 1993 & 293 & 209 \\
\hline 1992 & 213 & 172 \\
\hline 1991 & 363 & 218 \\
\hline 1990 & 174 & 116 \\
\hline 1989 & 125 & 96 \\
\hline 1988 & 158 & 130 \\
\hline 1987 & 121 & 93 \\
\hline 1986 & 129 & 126 \\
\hline 1985 & 275 & 226 \\
\hline 1984 & 583 & 429 \\
\hline 1983 & 491 & 370 \\
\hline 1982 & 282 & 234 \\
\hline 1981 & 407 & 223 \\
\hline 1980 & 183 & 84 \\
\hline 1979 & 209 & \\
\hline 1978 & & 158 \\
\hline & & \\
\hline & & \\
\hline & & \\
\hline & & \\
\hline & & \\
\hline
\end{tabular}




\begin{tabular}{|l|l|l|}
\hline 1977 & 174 & 141 \\
\hline 1976 & 197 & 156 \\
\hline 1975 & 227 & 190 \\
\hline 1974 & 434 & 433 \\
\hline 1973 & 326 & 251 \\
\hline 1972 & 244 & 216 \\
\hline 1971 & 211 & 196 \\
\hline 1970 & 163 & 147 \\
\hline 1969 & 117 & 113 \\
\hline
\end{tabular}

\section{Sources:}

B. Williams (Chair), Report of the Committee on Obscenity and Film Censorship (Cmnd 7772, 1979) (for 1969-1978).

HC Deb. 17 February 1997 vol. 290, col 358-361W (for 1980-1982 and 1984-1995).*

HC Deb, 13 July 1992, vol 211, col 496W (for 1982-1990).** Note that this source gives a different result for 1981 with 347 prosecuted and 211 found guilty. Compare HC Deb, 4 May 1989, vol 152, col WA236 for conflicting figures for prosecutions between 1982-1987.

HL Deb, 10 March 1998, vol 587, col WA28-29 (1991-1996).*

HL Deb, 15 Jan 2001, vol 620, col WA101-102. (1997-1999).**

HC Deb, 19 September 2002 vol 390, col 68-69W (for 2000).

HC Deb, 16 February 2006, vol 442, col 2352W (for 2002-2004).

Freedom of Information Act 2000 request by the author to the Ministry of Justice (2005-2015).

Ministry of Justice, Criminal Justice System Statistics Quarterly: December 2016 (May 2017) (for 2016).

Table 3: s.1 of the Protection of Children Act 1978 in England and Wales

\begin{tabular}{|l|l|l|l|}
\hline & Prosecuted & Convicted & Cautions \\
\hline 2016 & 3063 & 2890 & 221 \\
\hline 2015 & 2374 & 1994 & 185 \\
\hline 2014 & 1921 & 1526 & 163 \\
\hline 2013 & 1695 & 1392 & 208 \\
\hline 2012 & 1466 & 1315 & 210 \\
\hline 2011 & 1524 & 1283 & 208 \\
\hline 2010 & 1501 & 1246 & 155 \\
\hline 2009 & 1240 & 1024 & 187 \\
\hline 2008 & 1136 & 958 & 178 \\
\hline 2007 & 888 & 782 & 185 \\
\hline 2006 & 937 & 768 & 168 \\
\hline 2005 & 1101 & 958 & 195 \\
\hline 2004 & 1097 & 978 & 201 \\
\hline 2003 & 1464 & 1048 & 239 \\
\hline 2002 & 582 & 434 & 63 \\
\hline 2001 & 398 & 289 & 38 \\
\hline 2000 & 284 & 218 & 35 \\
\hline 1999 & 175 & 139 & 31 \\
\hline 1998 & 116 & 82 & 26 \\
\hline 1997 & 111 & 103 & 14 \\
\hline 1996 & 80 & 69 & 15 \\
\hline & & & \\
\hline & 102 & & \\
\hline
\end{tabular}




\begin{tabular}{|l|l|l|l|}
\hline 1995 & 53 & 44 & \\
\hline 1994 & 40 & 27 & \\
\hline 1993 & 42 & 37 & \\
\hline 1992 & 46 & 44 & \\
\hline 1991 & 40 & 39 & \\
\hline 1990 & 44 & 35 & \\
\hline 1989 & 44 & 39 & \\
\hline 1988 & 32 & 31 & \\
\hline 1987 & 23 & 29 & \\
\hline 1986 & 10 & 11 & \\
\hline 1985 & 22 & 24 & \\
\hline 1984 & 18 & 19 & \\
\hline 1983 & & & \\
\hline 1982 & 9 & 12 & \\
\hline 1981 & 13 & 14 & \\
\hline 1980 & 13 & 13 & \\
\hline
\end{tabular}

\section{Sources:}

HC Deb. 17 February 1997 vol. 290, c .358-361W (for 1980-1995).*

S.Ost, Child Pornography and Sexual Grooming (Cambridge University Press, 2009) p.93 (for 19962004).*

Ministry of Justice, Criminal Justice System Statistics Quarterly: December 2014 (May 2015) (for 2004).

Ministry of Justice, Criminal Justice System Statistics Quarterly: December 2015 (May 2016) (for 2005).

Ministry of Justice, Criminal Justice System Statistics Quarterly: December 2016 (May 2017) (for 2006-2016).

Table 4: Possession of Indecent Images of Children (s.160 offences) in England and Wales

\begin{tabular}{|l|l|l|l|}
\hline & Prosecutions & Convictions & Cautions \\
\hline 2016 & 531 & 554 & 222 \\
\hline 2015 & 466 & 481 & 208 \\
\hline 2014 & 318 & 345 & 198 \\
\hline 2013 & 266 & 284 & 272 \\
\hline 2012 & 234 & 247 & 294 \\
\hline 2011 & 200 & 246 & 272 \\
\hline 2010 & 292 & 165 & 215 \\
\hline 2009 & 235 & 222 & 186 \\
\hline 2008 & 240 & 227 & 167 \\
\hline 2007 & 185 & 184 & 142 \\
\hline 2006 & 162 & 162 & 147 \\
\hline 2005 & 160 & 177 & 147 \\
\hline 2004 & 159 & 162 & 154 \\
\hline 2003 & 326 & 239 & 205 \\
\hline 2002 & 156 & 97 & 53 \\
\hline
\end{tabular}




\begin{tabular}{|l|l|l|l|}
\hline 2001 & 88 & 51 & 25 \\
\hline 2000 & 129 & 77 & 25 \\
\hline 1999 & 163 & 99 & 34 \\
\hline 1998 & 167 & 105 & 19 \\
\hline 1997 & 124 & 81 & 17 \\
\hline 1996 & 125 & 79 & 16 \\
\hline
\end{tabular}

\section{Sources:}

HL Deb, 15 Jan 2001, vol 620, col WA101-102. (for 1997-1999).**

S. Ost, Child Pornography and Sexual Grooming (Cambridge University Press, 2009) (1996-2003), p.93 (note that the figures given by the source for 2004-2006 differ from those provided in the table above).

HC Deb, 19 September 2002 vol 390 col 68-69W (for 2000).

Ministry of Justice, Criminal Justice System Statistics Quarterly: December 2014 (May 2015) (for 2004).

Ministry of Justice, Criminal Justice System Statistics Quarterly: December 2015 (May 2016) (for 2005).

Ministry of Justice, Criminal Justice System Statistics Quarterly: December 2016 (May 2017) (for 2006-2016).

Table 5: Possession of Prohibited Images in England and Wales

\begin{tabular}{|l|l|l|l|}
\hline & Prosecutions & Convictions & Cautions \\
\hline 2016 & 39 & 47 & 15 \\
\hline 2015 & 21 & 24 & 18 \\
\hline 2014 & 18 & 7 & 17 \\
\hline 2013 & 18 & 14 & 15 \\
\hline 2012 & 15 & 8 & 14 \\
\hline 2011 & 6 & 6 & 12 \\
\hline 2010 & & & 2 \\
\hline
\end{tabular}

Source

Ministry of Justice, Criminal Justice System Statistics Quarterly: December 2016 (May 2017).

Table 6: Possession of Extreme Pornography in England and Wales

\begin{tabular}{|l|l|}
\hline & Convictions \\
\hline 2016 & 121 \\
\hline 2015 & 116 \\
\hline 2014 & 91 \\
\hline 2013 & 82 \\
\hline 2012 & 78 \\
\hline 2011 & 81 \\
\hline
\end{tabular}

Sources:

HC Deb, 28 March 2017, col W68914 (for 2011-2015).

Ministry of Justice, Criminal Justice System Statistics Quarterly: December 2016 (May 2017). 